\title{
Directions of changes in the flora structure in the abandoned railway areas
}

\section{"Halina Galera, "Barbara Sudnik-Wójcikowska, "Małgorzata Wierzbicka, "*Bogusław Wiłkomirski}

\author{
"Institute of Botany, University of Warsaw, \\ Al. Ujazdowskie 4, 00-478 Warsaw, Poland \\ e-mail: h.galera@uw.edu.pl \\ ${ }^{* *}$ Faculty of Mathematics and Natural Sciences, The Jan Kochanowski University, \\ Świetokrzyska 15, 25-406 Kielce, Poland
}

\begin{abstract}
In 2007-2008, floristic studies were carried out in active railway areas in NE Poland, as well as on railway tracks, which had been abandoned at different times. Only homogeneous habitats were surveyed (the area between the tracks and a narrow transect running parallel to the tracks). Trends in the transformation of the flora in abandoned railway areas were discussed: the retreat of alien species with a short life cycle, the encroachment of native perennial plants and an increase in the number of trees.
\end{abstract}

Key words: railway lines, plant encroachment, regeneration of the flora, NE Poland.

\section{Introduction}

The first railway lines were opened in Great Britain in 1830 (Brandes 2008). Since then railway transport has become one of the most important factor affecting the process of flora synanthropization (first publications - e.g. Eggert 1891; Lehmann 1895, in Poland e.g. Kornaś et al. 1959). Railway has greatly influenced a structure of local ecosystems. Threats resulting from fragmentation of natural and seminatural biotopes were observed in various parts of the world (Europe - e.g. Tikka et al. 2000; Gontier et al. 2006; other continents e.g. Chen et al. 2003; Hansen \& Clevenger 2005).

Based on the observed migration of species along railway lines, it appears that these areas act as ecological corridors (see e.g. Kopecky 1971; Jehlik 1986; Gilbert 1989; Brandes 1993a, b, 2005; Brandes \& Oppermann 1995; Büscher et al. 2008; Radkowitsch 2003; Latowski \& Pardoł 2004; Hansen \& Clevenger 2005). The consequences of migrations along railways ("ferroviatische Migrationen”, Kopecky 1971; Brandes \& Oppermann
$1995)$ were presented in a number of papers (e.g. Brandes 1993a; Böhmer 2001; Büscher et al. 2008; Wiłkomirski et al. 2012) described the further fate of species spreading along the railways. After 180 years, railway tracks still act as an ecological corridor for new species of plants (Hohla et al. 2000, 2002; Latowski \& Musiatowicz 2005; Nobis $\&$ Nobis 2006). Railway stations, which are the major trans-shipment points for goods, are usually located in big cities. They are recognized as "hot spots" for expansion of synanthropic plants. Over last several decades new transport technology has been introduced (container trains - see Brandes 1993a, 2005). In addition the growth of plants along railway tracks has been limited due to the extensive use of herbicides (Kowarik \& Tietz 1986; Gilbert 1989; Brandes \& Oppermann 1995; Brandes 1993a, 2005; Wittig 2002). Recently attempts have been made to apply alternative weed control methods (Brandes 1993a). In the past, however, the following maintenance procedures were more frequently used: weeding, mowing, burning and tree cutting (Suominen 1969; Sendek 1973; Wrzesień \& Święs 2006). 


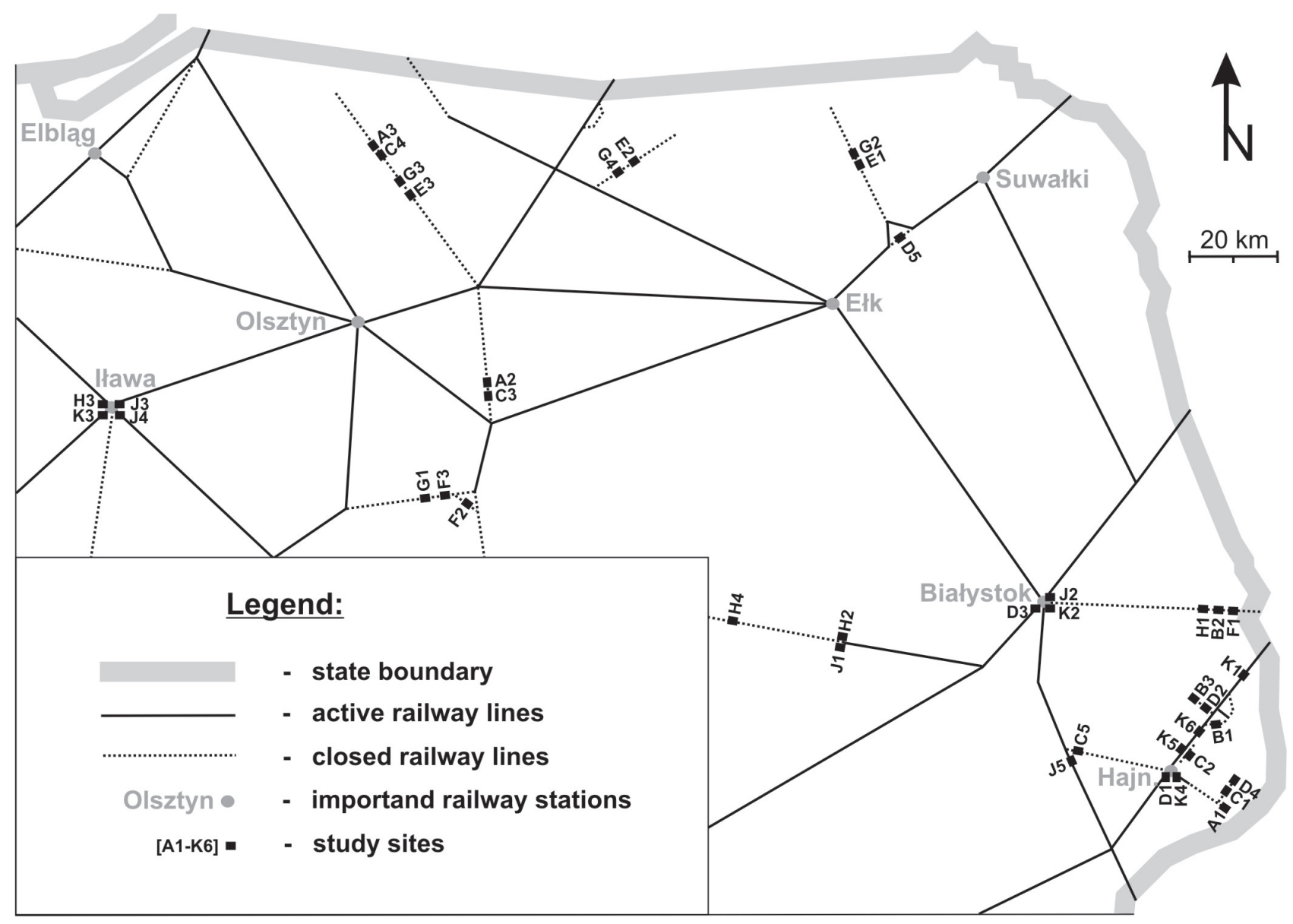

Figure 1. Railroad network in NE Poland and the location of the study sites. The study sites were designated as follows: A, B, C, D - railway tracks abandoned over 10 years ago; E, F, G, H - railway tracks abandoned less than 10 years ago; J, K - active railway tracks

There is a number of papers dealing with dynamics of the plant cover on active railway tracks (see Brandes 2008). However, processes accompanying the development of the flora in abandoned railway areas are not well recognized. For example, some authors (e.g. Kowarik \& Tietz 1986; Kowarik \& Langer 1994, 2005; Schinninger et al. 2002, 2003; Brandes 2002a, 2004a; Galera et al. 2011) conducted their studies on closed railway stations. There are only few publications concerned with abandoned railway tracks between the stations (Sendek 1973; Brandes 1993a; Brandes \& Oppermann 1995; Kryszak et al. 2006; Fornal-Pieniek \& Wysocki 2010).

Development of the road transport industry and the economical changes in Poland (after 1989) resulted in the closure of number of railway lines (Piskorz \& Czarna 2006; Wrzesień \& Święs 2006, Nowińska \& Czarna 2008). This process is still taking place, which enables floristic observations within railway areas abandoned at different times. The present work focuses on the process of development of the vascular flora in active and abandoned railway areas. The aim of this study is to determine the directions of changes in the structure of the flora (i.e. changes in the proportion of particular groups of species) in abandoned railway areas.

\section{Study area}

In the years 2007-2008 floristic observations were carried out at 41 sites along the railway tracks in NE Poland (Fig. 1 and Table 1). Sampling areas included:

- 11 sites located along operational railway tracks (hereafter referred to as "active").

- 14 sites located along railway tracks abandoned less than 10 years ago (referred to in the paper as "abandoned $<10$ "),

- 16 sites located along railway tracks abandoned more than ten years ago (hereafter referred to as "abandoned $>10$ ").

The study included almost all the closed railway lines in NE Poland (Fig. 1). In addition active railway areas adjacent to the unused tracks were investigated. At each study 
Table 1. Characteristics of the study sites. Surroundings - type of surrounding habitat: $\mathrm{df}-$ broadleaf forest, pf - coniferous forest, gr - grassland, ru - ruderal habitats

\begin{tabular}{|c|c|c|c|c|}
\hline$\frac{\pi}{8}$ & Locality & Coordinates & Status & Surroundings \\
\hline A1 & Białowieża Towarowa Station & $52^{\circ} 41^{\prime} 45,3^{\prime \prime} \mathrm{N} ; 23^{\circ} 50^{\prime} 39,8^{\prime \prime} \mathrm{E}$ & abandoned since 1995 & df \\
\hline $\mathrm{A} 2$ & Nowe Kiejkuty (sample 1) & $53^{\circ} 39^{\prime} 27,4^{\prime \prime} \mathrm{N} ; 21^{\circ} 02^{\prime} 16,1^{\prime \prime} \mathrm{E}$ & abandoned since 1993 & $\mathrm{df}$ \\
\hline A3 & Nerwiki & $54^{\circ} 10^{\prime} 49,1^{\prime \prime} \mathrm{N} ; 20^{\circ} 30^{\prime} 45,9^{\prime \prime} \mathrm{E}$ & abandoned since 1999 & df \\
\hline $\mathrm{B} 1$ & Nowosady (sample 1) & $52^{\circ} 46^{\prime} 53,2^{\prime \prime} \mathrm{N} ; 23^{\circ} 37^{\prime} 36,0^{\prime \prime} \mathrm{E}$ & abandoned since 1993 & $\mathrm{pf}$ \\
\hline $\mathrm{B} 2$ & Straszewo & $53^{\circ} 03^{\prime} 17,9^{\prime \prime} \mathrm{N} ; 23^{\circ} 55^{\prime} 05,3^{\prime \prime} \mathrm{E}$ & abandoned since 1990 & $\mathrm{pf}$ \\
\hline B3 & Narewka (sample 1) & $52^{\circ} 49^{\prime} 10,9^{\prime \prime} \mathrm{N} ; 23^{\circ} 45^{\prime} 01,9^{\prime \prime} \mathrm{E}$ & abandoned since 1994 & $\mathrm{pf}$ \\
\hline $\mathrm{C} 1$ & Białowieża Pałac Station (sample 1) & $52^{\circ} 41^{\prime} 32,3$ ” N; 2350’04,3” E & abandoned since 1995 & gr \\
\hline $\mathrm{C} 2$ & Nowosady (sample 2) & $52^{\circ} 46^{\prime} 53,2^{\prime \prime} \mathrm{N} ; 23^{\circ} 37^{\prime} 36,0^{\prime \prime} \mathrm{E}$ & abandoned since 1993 & gr \\
\hline $\mathrm{C} 3$ & Nowe Kiejkuty (sample 2) & $53^{\circ} 38^{\prime} 53,9^{\prime \prime} \mathrm{N} ; 21^{\circ} 02^{\prime} 03,6^{\prime \prime} \mathrm{E}$ & abandoned since 1993 & gr \\
\hline $\mathrm{C} 4$ & Nowa Wieś Wielka & $54^{\circ} 10^{\prime} 49,1^{\prime \prime} \mathrm{N} ; 20^{\circ} 30^{\prime} 45,9^{\prime \prime} \mathrm{E}$ & abandoned since 1999 & gr \\
\hline $\mathrm{C} 5$ & Lewki (sample 1) & $52^{\circ} 42^{\prime} 04,0^{\prime \prime} \mathrm{N} ; 23^{\circ} 12^{\prime} 21,3^{\prime \prime} \mathrm{E}$ & abandoned since 1995 & gr \\
\hline D1 & Hajnówka (sample 1) & $52^{\circ} 37^{\prime} 35,4^{\prime \prime} \mathrm{N} ; 23^{\circ} 39^{\prime} 12,9^{\prime \prime} \mathrm{E}$ & abandoned since 1993 & $\mathrm{ru}$ \\
\hline D2 & Narewka (sample 2) & $52^{\circ} 13^{\prime} 21,6^{\prime \prime} \mathrm{N} ; 23^{\circ} 44^{\prime} 56,5^{\prime \prime} \mathrm{E}$ & abandoned since 1994 & $\mathrm{ru}$ \\
\hline D3 & Białystok Fabryczny Station (sample 1) & $53^{\circ} 06^{\prime} 53,2^{\prime \prime} \mathrm{N} ; 23^{\circ} 11^{\prime} 18,9^{\prime \prime} \mathrm{E}$ & abandoned since 1985 & $\mathrm{ru}$ \\
\hline $\mathrm{D} 4$ & Białowieża Pałac Station (sample 2) & $52^{\circ} 41^{\prime} 32,3 ” \mathrm{~N} ; 23^{\circ} 50^{\prime} 04,3$ ” E & abandoned since 1995 & ru, gr \\
\hline D5 & Olecko & $54^{\circ} 01 ’ 21,3 ” \mathrm{~N} ; 22^{\circ} 30^{\prime} 33,9^{\prime \prime} \mathrm{E}$ & abandoned since 1982 & ru, gr \\
\hline E1 & Pogorzel (sample 1) & $54^{\circ} 13^{\prime} 32,2^{\prime \prime} \mathrm{N} ; 22^{\circ} 24^{\prime} 59,3{ }^{\prime \prime} \mathrm{E}$ & abandoned since 2000 & $\mathrm{df}$ \\
\hline E2 & Gierłoż & $54^{\circ} 04^{\prime} 45,2^{\prime \prime} \mathrm{N} ; 21^{\circ} 29^{\prime} 39,7^{\prime \prime} \mathrm{E}$ & abandoned since 2000 & df \\
\hline E3 & Tolniki & $54^{\circ} 04^{\prime} 02,4 ” \mathrm{~N} ; 20^{\circ} 42^{\prime} 49,2^{\prime \prime} \mathrm{E}$ & abandoned since 2000 & df \\
\hline F1 & Zubki Białostockie & $53^{\circ} 033^{\prime} 33,6^{\prime \prime} \mathrm{N} ; 23^{\circ} 55^{\prime} 03,7^{\prime \prime} \mathrm{E}$ & abandoned since 2000 & pf \\
\hline $\mathrm{F} 2$ & Suchy Las & $53^{\circ} 23^{\prime} 04,0^{\prime \prime} \mathrm{N} ; 20^{\circ} 55^{\prime} 46,5^{\prime \prime} \mathrm{E}$ & abandoned since 2000 & $\mathrm{pf}$ \\
\hline F3 & Wielbark & $53^{\circ} 22^{\prime} 34,0^{\prime \prime} \mathrm{N} ; 20^{\circ} 51^{\prime} 41,6$ "' E & abandoned since 2000 & $\mathrm{pf}$ \\
\hline G1 & Puchałowo & $53^{\circ} 21^{\prime} 56,5^{\prime \prime} \mathrm{N} ; 20^{\circ} 44^{\prime} 53,6^{\prime \prime} \mathrm{E}$ & abandoned since 2000 & gr \\
\hline $\mathrm{G} 2$ & Pogorzel (sample 2) & $54^{\circ} 13^{\prime} 49,1^{\prime \prime} \mathrm{N} ; 22^{\circ} 25^{\prime} 00,9^{\prime \prime} \mathrm{E}$ & abandoned since 2000 & gr \\
\hline G3 & Czarny Kierz & $54^{\circ} 04^{\prime} 53,3^{\prime \prime} \mathrm{N} ; 20^{\circ} 39^{\prime} 41,0^{\prime \prime} \mathrm{E}$ & abandoned since 2000 & gr \\
\hline G4 & Czerniki & $54^{\circ} 05^{\prime} 05,6^{\prime \prime} \mathrm{N} ; 21^{\circ} 25^{\prime} 58,6^{\prime \prime} \mathrm{E}$ & abandoned since 2000 & gr \\
\hline $\mathrm{H} 1$ & Waliły & $53^{\circ} 05^{\prime} 09,4^{\prime \prime} \mathrm{N} ; 23^{\circ} 38^{\prime} 11,6^{\prime \prime} \mathrm{E}$ & abandoned since 2000 & $\mathrm{ru}$ \\
\hline $\mathrm{H} 2$ & Sokoły (sample 1) & $52^{\circ} 58^{\prime} 23,2^{\prime \prime} \mathrm{N} ; 22^{\circ} 43^{\prime} 44,6^{\prime \prime} \mathrm{E}$ & abandoned since 2005 & $\mathrm{ru}$ \\
\hline H3 & Iława (sample 1) & 5334'49,0” N; 19³4’20,1” E & abandoned since 2005 & $\mathrm{ru}$ \\
\hline $\mathrm{H} 4$ & Kołaki & $53^{\circ} 00^{\prime} 58,1^{\prime \prime} \mathrm{N} ; 22^{\circ} 21^{\prime} 21,8^{\prime \prime} \mathrm{E}$ & abandoned since 2000 & pf, gr \\
\hline $\mathrm{J} 1$ & Sokoły (sample 2) & $52^{\circ} 58^{\prime} 43,6^{\prime \prime} \mathrm{N} ; 22^{\circ} 44^{\prime} 13,9^{\prime \prime} \mathrm{E}$ & not intensively used & $\mathrm{ru}$ \\
\hline $\mathrm{J} 2$ & Białystok Fabryczny Station (sample 2) & $53^{\circ} 08^{\prime} 12,0^{\prime \prime} \mathrm{N} ; 23^{\circ} 11^{\prime} 39,5^{\prime \prime} \mathrm{E}$ & not intensively used & $\mathrm{ru}$ \\
\hline $\mathrm{J} 3$ & Iława (sample 2) & 533'09,4” N; 19³4'39,7” E & not intensively used & $\mathrm{ru}$ \\
\hline $\mathrm{J} 4$ & Iława (sample 3) & $53^{\circ} 34^{\prime} 67,5^{\prime \prime} \mathrm{N} ; 19^{\circ} 34^{\prime} 34,0^{\prime \prime} \mathrm{E}$ & not intensively used & ru \\
\hline $\mathrm{J} 5$ & Lewki (sample 2) & $52^{\circ} 40^{\prime} 55,9^{\prime \prime} \mathrm{N} ; 23^{\circ} 12^{\prime} 03,5^{\prime \prime} \mathrm{E}$ & intensively used & gr \\
\hline K1 & Siemianówka & $52^{\circ} 52^{\prime} 38,8^{\prime \prime} \mathrm{N} ; 23^{\circ} 56^{\prime} 09,2^{\prime \prime} \mathrm{E}$ & intensively used & $\mathrm{ru}$ \\
\hline K2 & Białystok Fabryczny Station (sample 3) & $53^{\circ} 06^{\prime} 32,0^{\prime \prime} \mathrm{N} ; 23^{\circ} 12^{\prime} 20,9^{\prime \prime} \mathrm{E}$ & intensively used & ru \\
\hline K3 & Iława (sample 4) & 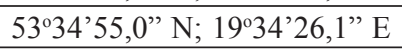 & intensively used & $\mathrm{ru}$ \\
\hline K4 & Hajnówka (sample 2) & $52^{\circ} 37^{\prime} 36,0^{\prime \prime} \mathrm{N} ; 23^{\circ} 39^{\prime} 17,0^{\prime \prime} \mathrm{E}$ & intensively used & $\mathrm{ru}$ \\
\hline K5 & Nowosady (sample 3) & $52^{\circ} 46^{\prime} 53,2^{\prime \prime} \mathrm{N} ; 23^{\circ} 37^{\prime} 36,0^{\prime \prime} \mathrm{E}$ & intensively used & gr \\
\hline K6 & Nowosady (sample 4) & $52^{\circ} 36^{\prime} 35,4^{\prime \prime} \mathrm{N} ; 23^{\circ} 36^{\prime} 27,7^{\prime \prime} \mathrm{E}$ & intensively used & $\mathrm{pf}$ \\
\hline
\end{tabular}

site, $120 \mathrm{~m}^{2}$ of railway track were surveyed, including the area between the tracks and two sections along both sides of the railway.

\section{Material and methods}

Comparative analysis of the flora of railway areas abandoned more than 10 years ago, railway areas abandoned less than 10 years ago and operational railway tracks was conducted. The floristic composition was analysed with respect to: species richness, species frequency, dispersal 
strategy, spectrum of life forms (Raunkiaer 1934), spectrum of groups of synanthropic species (distinguished in the geographical-historical classification of Kornaś 1982), classification of native plants (forest, grassland, ruderal species). Autochtonous species were divided into ephemeral apophytes (native species vulnerable to human impact which occure very rarely in anthropogenic habitats) and euapophytes.

In order to analyse the spectrum of life forms and groups of synanthropes, a group of highly frequent species was determined. Furthermore, three groups of species (hereafter referred to as the "species occurring exclusively in one type of railway area") were distinguished:

- plants occurring only along railway tracks "abandoned $>10$ ",

- plants growing only along railway tracks "abandoned $<10$ ",

- plants found only along active railway tracks.

\section{Results}

A total of 338 species were recorded at 41 sites investigated. The most frequently encountered species (frequency $>70 \%$ ) were: Arrhenatherum elatius (L.) P. Beauv. ex J. Presl et C. Presl, Artemisia campestris L., A. vulgaris L., Medicago lupulina L., Poa compressa L., Rumex acetosa L. and Taraxacum sp. sect. Vulgaria. These plants are classified as apophytes, most of which came from the grassland habitats (only Artemisia vulgaris arrived from a forest).

The flora of the investigated railway areas was characterized by:

- the dominance of hemicryptophytes (49\% of the flora, see Table 2);

- the dominance of native species - euapophytes and ephemeral apophytes $(59 \%$ and $17 \%$ of the flora, respectively, see Table 3 );

- the dominance of plants producing light generative diasporas, which can be dispersed through anemochory (wind dispersal, 256 species $-76 \%$ of the flora).

A relatively high number of woody plants was recorded (50 species of phanerophytes, Table 2). It should be noted, however, that most of these species were represented by seedlings or juvenile specimens. Mature trees and shrubs were observed only in several abandoned railway areas (sites: A1-3, B1-3, C4, D1, D3-5, E1 and F2 in Table 1).

Comparative analysis of the flora of "active tracks", railway areas "abandoned $<10$ " and railway areas "abandoned $>10$ " revealed changes in the structure of the flora as a result of closure of the railway lines (Fig. 2). The flora of railway areas where train activity stopped more than 10 years ago exhibited:
Table 2. Spectrum of life forms in the flora of the 41 sites investigated (all the investigated areas) and in the flora of: active railway areas (active), railway areas abandoned less than 10 years ago (abandoned $<10$ ), railway areas abandoned over 10 years ago (abandoned $>10$ )

\begin{tabular}{|l|c|c|c|c|}
\hline \multirow{2}{*}{\multicolumn{1}{|c|}{ Life form }} & \multicolumn{4}{|c|}{$\begin{array}{c}\text { Number of species in the flora of } \\
\text { railway areas: }\end{array}$} \\
\cline { 2 - 5 } & $\begin{array}{c}\text { all the in- } \\
\text { vestigated } \\
\text { areas }\end{array}$ & active & $\begin{array}{c}\text { aban- } \\
\text { doned } \\
<10\end{array}$ & $\begin{array}{c}\text { aban- } \\
\text { doned } \\
>10\end{array}$ \\
\hline phanerophytes & 50 & 18 & 32 & 42 \\
\hline chamaephytes & 16 & 8 & 11 & 14 \\
\hline geophytes & 22 & 8 & 14 & 21 \\
\hline hemicryptophytes & 166 & 67 & 122 & 139 \\
\hline therophytes & 81 & 69 & 46 & 40 \\
\hline life form unclear & 3 & 2 & 1 & 0 \\
\hline Total & 338 & 172 & 226 & 256 \\
\hline
\end{tabular}

- the highest species richness (a total of 256 species were found along the railway tracks "abandoned $>10$ ", Fig. 2A);

- the lowest frequency of occurrence of species (the mean frequency of the species noted in the above railway areas was estimated to be $22 \%$, Fig. 2B);

- the lowest proportion of species producing light diasporas, which can be dispersed through anemochory (Fig. 2C);

- the lowest proportion of species with a short life cycle (therophytes comprised $16 \%$ of the flora, Fig. 2D and Table 2);

- the highest percentage of native species in the flora (84\%), and the lowest proportion of established alien plants (archaeophytes made up 6\% of the flora, whereas kenophytes 7\%, Fig. 2E and Table 3);

- the highest proportion of native forest species $(34 \%$, Fig. 2F).

It should be noted that the differences in the flora were consistent with our expectations. Extreme data were gathered from railway areas abandoned more than 10 years ago and still-active railway tracks, whereas floristic parameters for railway lines closed less than 10 years ago were of intermediate levels. In the case of active railway tracks the proportion of therophytes and alien species was much higher than in abandoned railway areas (see Figs. 2D and $2 \mathrm{E}$ ).

Analysis of the data regarding the mean species richness (Fig. 2A) and mean frequency of species (Fig. 2B) along the investigated railway tracks indicated that the species composition has not change in the case of active railway tracks. The flora of railway areas which had been abandoned more than 10 years ago was more diversified 
A

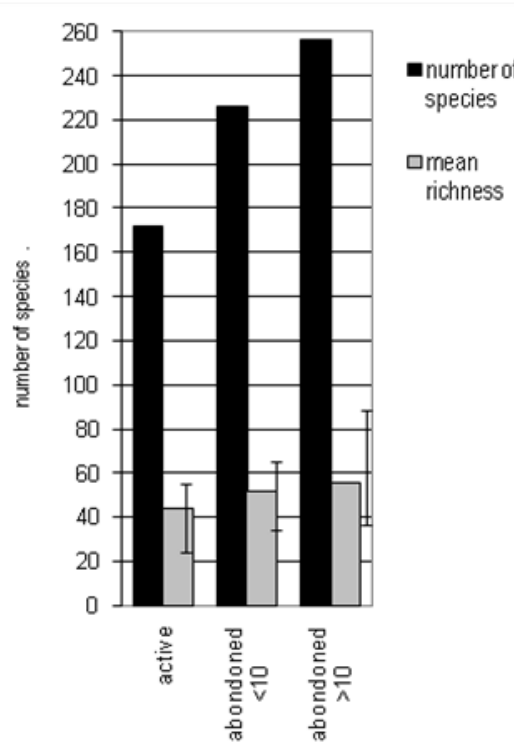

D

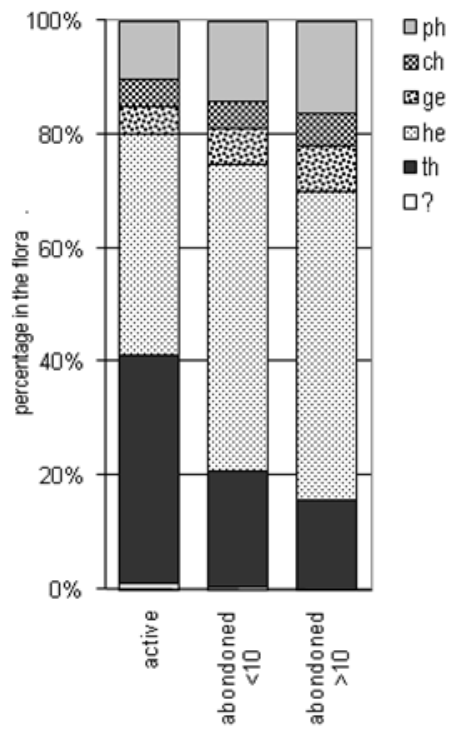

B

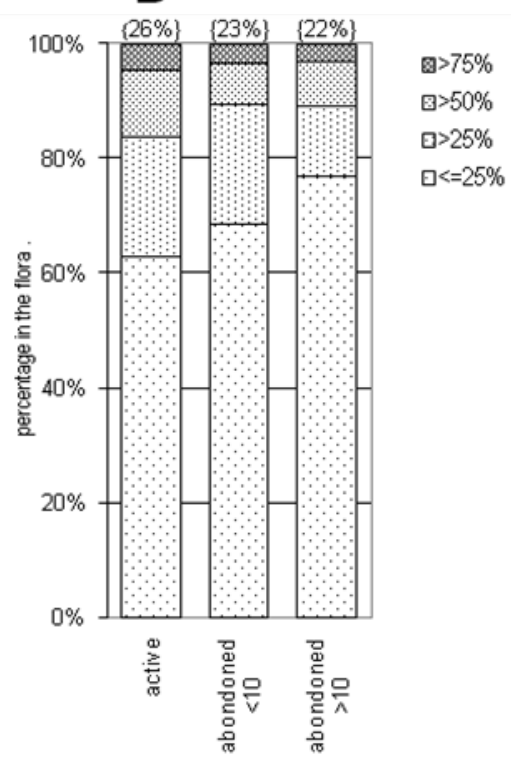

E

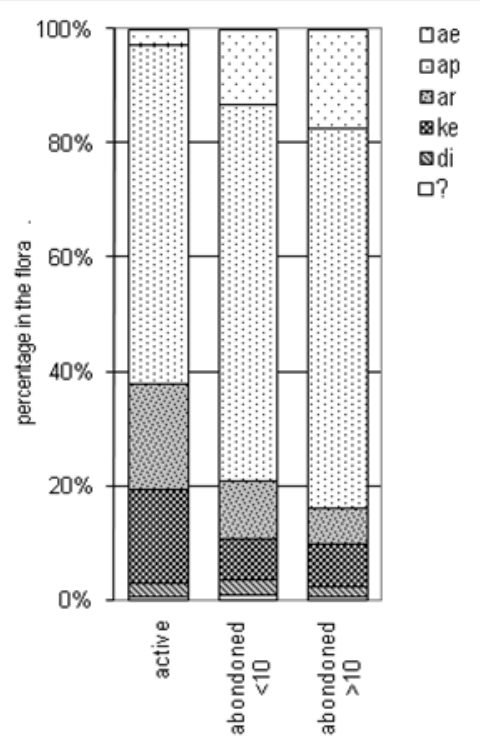

C

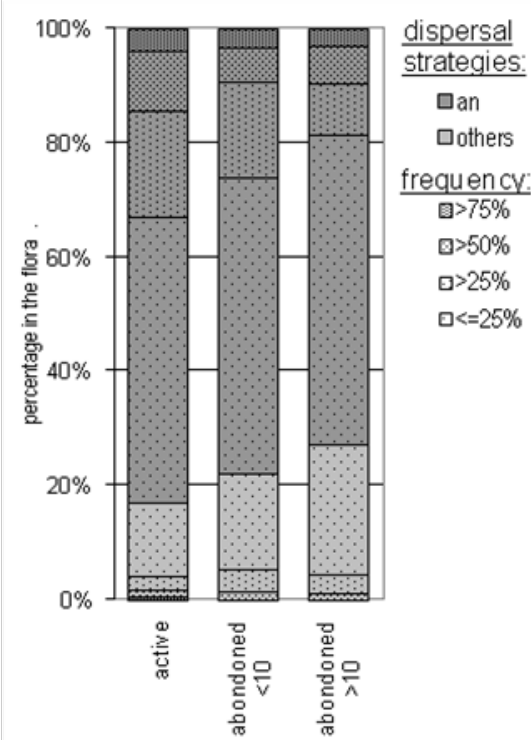

$\mathbf{F}$

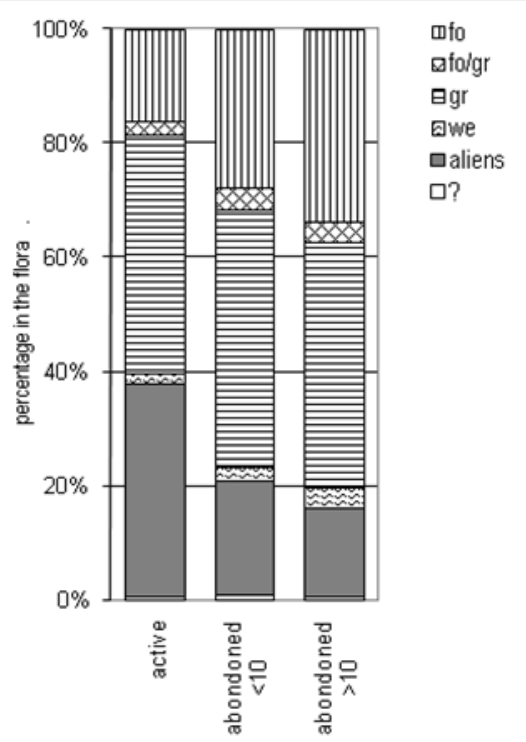

Figure 2. Comparison of the flora of active railway areas (active), railway areas abandoned less than 10 years ago (abandoned $<10$ ), railway areas abandoned over 10 years ago (abandoned $>10$ ) with regard to: A - species richness; B - frequency of particular species (the mean frequency of species in a given type of railway area is given in brackets \{\} ); $\mathrm{C}$ - dispersal strategy (an - species producing diaspores which can be dispersed through anemochory, others - species whose diaspores cannot be dispersed through the action of wind); D - spectrum of life forms (ch - chamaephyte, ge - geophyte, he - hemicryptophyte, ph - phanerophyte, th - therophyte, ? - life form unclear); E - spectrum of synanthropes (ae - ephemeral apophyte, ap - euapophyte, ar - archaeophyte, di - diaphyte, ke - kenophyte, ? - status unclear); F - the natural occurrence of indigenous species in: fo - forests, fo/gr - forests and grasslands, gr - grasslands, we - wetlands; aliens - species of alien origin, ? - origin unclear 
Table 3. Spectrum of groups of synanthropes in the flora of the 41 sites investigated (all the investigated areas) and in the flora of: active railway areas (active), railway areas abandoned less than 10 years ago (abandoned $<10$ ), railway areas abandoned over 10 years ago (abandoned $>10)$

\begin{tabular}{|l|c|c|c|c|}
\hline \multirow{2}{*}{$\begin{array}{c}\text { Group of } \\
\text { synanthropes }\end{array}$} & \multicolumn{4}{|c|}{$\begin{array}{c}\text { Number of species in the flora of } \\
\text { railway areas: }\end{array}$} \\
\cline { 2 - 5 } & $\begin{array}{c}\text { all the in- } \\
\text { vestigated } \\
\text { areas }\end{array}$ & active & $\begin{array}{c}\text { aban- } \\
\text { doned } \\
<10\end{array}$ & $\begin{array}{c}\text { aban- } \\
\text { doned } \\
>10\end{array}$ \\
\hline ephemeral apophytes & 57 & 5 & 30 & 45 \\
\hline euapophytes & 199 & 102 & 149 & 170 \\
\hline archaeophytes & 36 & 32 & 23 & 16 \\
\hline kenophytes & 34 & 28 & 16 & 19 \\
\hline diaphytes & 9 & 4 & 6 & 5 \\
\hline status unclear & 3 & 1 & 2 & 1 \\
\hline Total & 338 & 172 & 226 & 256 \\
\hline
\end{tabular}

A

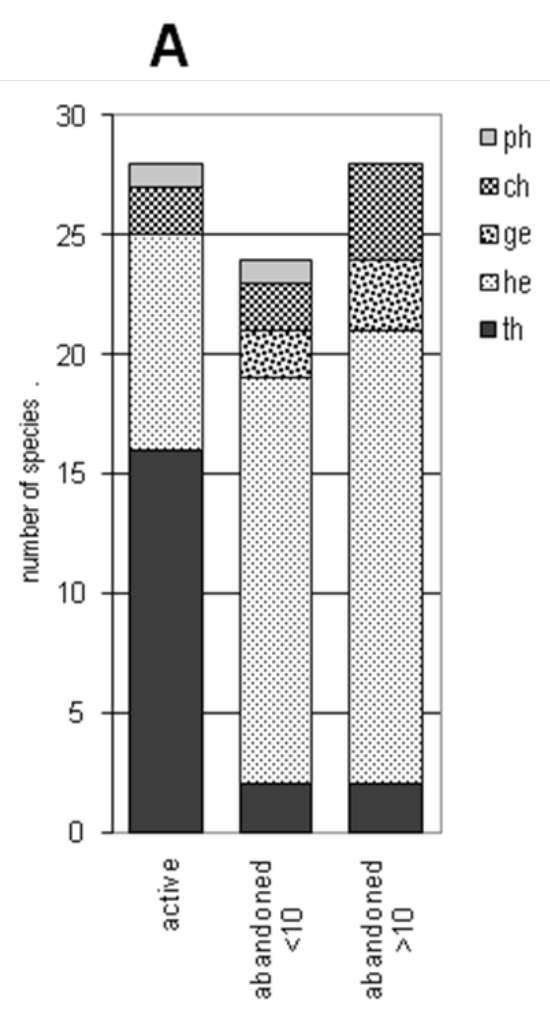

in terms of species composition. It was richer in species occurring with a quite low frequency.

\subsection{Most widespread species}

The number of species which occurred with more than $50 \%$ frequency was almost identical for all the 3 types of railway areas investigated in the study (areas "abandoned $<10$ ", "abandoned $>10$ " and still-active railway tracks). However, the composition of frequent species in the area of active railway differed from that of the abandoned railway areas. The flora of active railway areas contained:

- the highest number of annual species (Fig. 3A),

- the highest number of alien species - both archeophytes and kenophytes (Fig. 3B).

\subsection{Species occurring exclusively in one type of rail- way area}

Among the 338 taxa recorded at 41 study sites, 128 species $(35 \%)$ were found to occur only in one type of railway area. We recorded:

- 64 species only along railway tracks "abandoned $>10$ ",

- 30 species only along railway tracks "abandoned $<10$ ",

- 34 species only along active railway tracks.
B

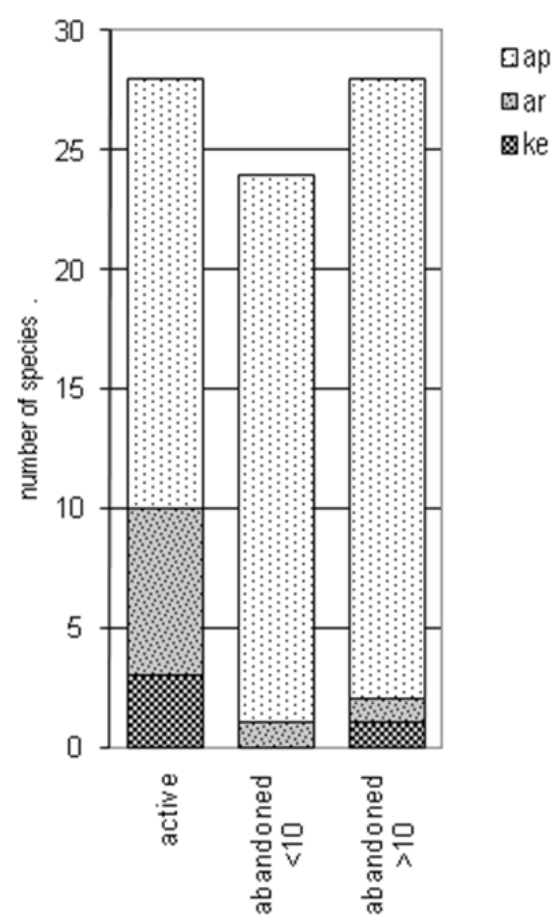

Figure 3. Comparison of the group of highly frequent species (frequency $>50 \%$ ) in active railway areas (active), railway areas abandoned less than 10 years ago (abandoned $<10$ ), railway areas abandoned over 10 years ago (abandoned $>10$ ) with regard to: $\mathrm{A}$ - spectrum of life forms (see Figure 2D for explanations), B - spectrum of synanthropes (see Figure 2E for explanations) 
A

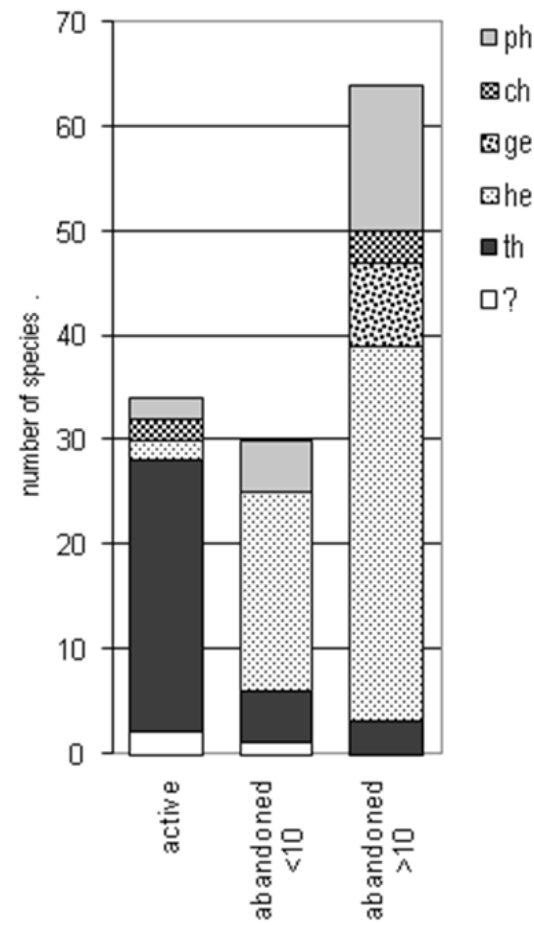

B

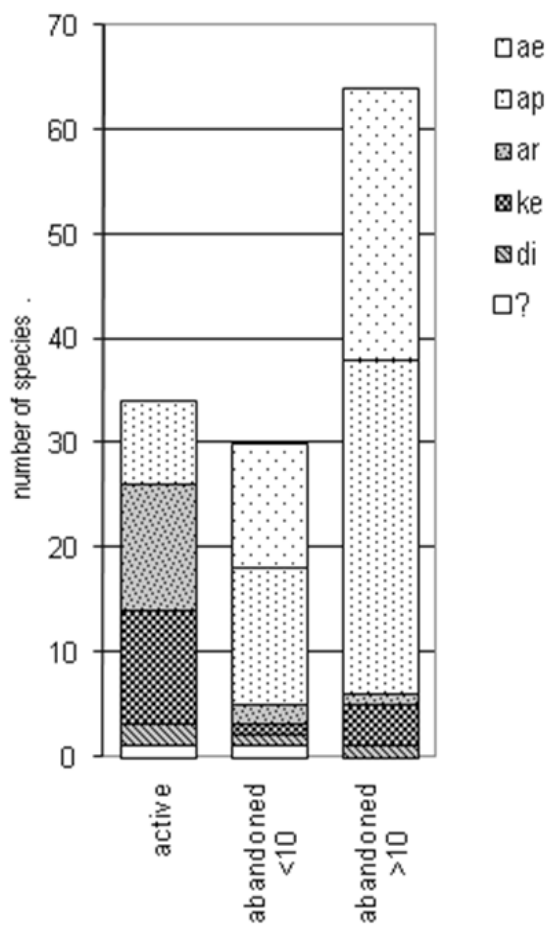

Figure 4. Comparison of the group of species occurring only along: active railway areas (active), railway areas abandoned less than 10 years ago (abandoned $<10$ ), railway areas abandoned over 10 years ago (abandoned $>10$ ), with regard to: A - spectrum of life forms (see Figure 2D for explanations), B - spectrum of synanthropes (see Figure 2E for explanations)

The majority of the species found exclusively along the tracks abandoned more than 10 years ago were hemicryptophytes (Fig. 4A) and native forest species (Fig. 4B). It is notable that among 57 ephemeral apophytes recorded at the 41 sites investigated, 26 species occurred only along the tracks that had not been in use for over 10 years.

The combination of species that occurred exclusively along active railway tracks was characterized by the dominance of annual and alien species. Among 81 species of recorded therophytes, 26 annual species were found exclusively along the tracks which were still in use (Fig. 4A and Table 2). Of the 79 allochtonous species recorded in the study area, 25 species occurred only along active railway tracks (Fig. 4B and Table 3).

A number of ephemeral apophytes (26 species) were found to occur exclusively along the tracks "abandoned $>10$ ". Twelve ephemeral apophytes were recorded only in railway areas "abandoned $<10$ " (Fig. 4B).

\section{Discussion}

As opposed to earlier publications that dealt with railway areas in a broad sense (including tracks, platforms, sta- tions, warehouse ramps, loading sidings, slopes of railway embankments, railway wastelands - see e.g. Brandes 1993a, 2005; Wittig 2002; Schinninger et al. 2002; Schinninger et al. 2003; Kowarik \& Langer 2004; Czarna 2005) our studies focused on one homogenous habitat type. We investigated only the area between the tracks and narrow side path. It was, therefore, rather difficult to make a direct comparison of the data obtained in this study and published literature.

Interesting results were obtained when the combinations of the most frequent species were compared. All the species which occurred with at least $70 \%$ frequency within the railway area investigated in this study were also widespread along railways in other regions of Poland (e.g. Sendek 1973; Wrzesień \& Święs 2006). Among these were species such as: Arrhenatherum elatius, Artemisia vulgaris, Medicago lupulina, Poa compressa and Taraxacum sp. sect. Vulgaria which were reported to occur frequently in railway areas in other European countries as well (e.g. Brandes 1983, 1993a; Jehlik 1986; Kowarik \& Tietz 1986; Gilbert 1989). Artemisia campestris and Rumex acetosa were found to be widespread within railway areas only in Harzvorland Niedersachsen and Sachsen-Anhalt (Brandes \& Oppermann 1995; Patrsch \& Karstner 1995). In the case 
of $A$. campestris this may be associated with disappearance of the species in western Europe, where the species reaches the north-eastern limit of its range (see Hulten \& Fries 1986). As for Rumex acetosa, it is not easy to distinguish this species from $R$. thyrsiflorus, which is regarded as being "typical of railway stations" in western Europe (Brandes 1983, 1993a; Brandes \& Operman 1995).

The observed directions of changes in the structure of the flora of the abandoned railway areas are consistent with the findings of other authors. In order to describe the process of reestablishment of the flora in abandoned railway areas the sites investigated in this study were divided into 3 groups: active railway tracks and two groups of abandoned railway areas (abandoned less than 10 years ago and over 10 years ago). This enabled us to gather and analyse quantitative data from the railway areas in north-eastern Poland.

\subsection{Retreat of species with short life cycle}

Many authors have recognized some alien species and plants with a short life cycle as being typical of the flora of railway areas. They indicated that these species were highly represented in the flora of railway areas (e.g. Kowarik \& Tietz 1986; Brandes \& Oppermann 1995; Partsch \& Karstner 1995; Brandes 2002b, 2004b; Schinninger et al. 2003). A number of publications contained lists of species associated with railway areas (e.g. Brandes 1983, 1993a, 2004a, 2005). The distribution dynamics of the species were also described (e.g. Brandes 1993b; Hohla et al. 2000, 2002; Schinninger et al. 2002; Radkowitsh 2003; Büscher et al. 2008). For example, Gilbert (1989) writes about "annual plant characteristic of railway" and "biennial characteristic of sidings where open conditions and intermittent disturbance favour their life style".

Therophytes and alien species also contributed significantly to the flora of active railway areas. Their role declined after the closure of the railway lines. Proportion of these groups of species in the flora was relatively small (see Tables 2 and 3). About 32\% of the recorded annual species and $32 \%$ of the alien taxa were found exclusively along still-active railway tracks (see Fig. 4 and Table 2). Therefore, the changes in the structure of the flora occurred rapidly - within several years after the train activity had stopped (as a result herbicides were no longer applied). Some authors of publications dealing with railway areas indicated the rapid retreat of species typical of anthropogenic habitats subjected to strong human impact (see e.g. Brandes 1993a, 2004b, 2005; Piskorz \& Czarna 2006; Nowińska \& Czarna 2008).

Over the course of time, the rate at which the alien and annual species disappear declined. As a result, the differences between the flora of railway areas abandoned more than 10 and railway areas abandoned less 10 years were less pronounced.

\subsection{Encroachment of native perennial species}

Due to the construction of railway the edaphic conditions within the railway area differ from those of the surrounding area. The following factors affect the growth of plants: high $\mathrm{pH}$ level of dry substrate, specific mechanical properties of the substrate (Sendek 1973; Brandes 1983, 2004b; Galera et al. 2009). These factors impede the encroachment of species (especially native plants that are sensitive to human pressure) into active as well as abandoned railway areas. The level of stress decreases with time after the tracks have been abandoned. The process of regeneration of the native flora depends mainly on the accessibility of diaspores produced by plants in the surroundings. The composition of the diaspore rain is largely determined by the plant community type occurring in the area adjacent to the tracks.

The composition of the diaspore rain varied considerably among the investigated areas of former railway as we included in the present study sections of the tracks running through ruderal areas as well as natural and seminatural plant communities (see Table 1). Due to the high availability of diaspores produced by native species the number of native plants increased after the railway areas had been abandoned. These included a number of species from different habitats (forests, grasslands and wet habitats, Fig. 3F). When compared to the flora of active railway areas (apophytes constituted 62\% of the flora of active tracks) autochtonous species were more highly represented in the flora of abandoned railway tracks (apophytes constituted $79 \%$ of the flora of railway areas "abandoned $>10$ " and $84 \%$ of the flora of areas "abandoned $<10$ "; Fig. $2 \mathrm{~F}$, the number of species is given in Table 3). Literature data indicate that even rare and threatened species can occur in railway areas in a broad sense. Latowski (1972); Brandes and Oppermann (1995); Schinninger et al. (2002); Święs \& Wrzesień (2002); Wittig (2002); Brandes (2004b); Piskorz \& Czarna (2006) suggested that abandoned railway areas could also play an important role as a refuge for rare and threatened species in the anthropogenic landscape.

\subsection{Tree growth as a result of changes in habitat}

The railway sites studied in the south-east of Poland contained a surprisingly high number of tree and shrub species (a total of 50 woody plants were recorded, Fig. 2D and Table 2). However, almost all of these species were represented by juvenile specimens. Sendek (1973) and Brandes (1993b, 2004b) also noted high abundance of tree seedlings within railway areas. In some cases trees can grow on railway embankments (Brandes 2008 mentions woody plants that occur only on railway verges). The further growth of phanerophytes along active railway tracks is impossible. In this case, the appearance of numerous seedlings in these 
areas every year is associated with the abundant supply of diaspores produced by trees and shrubs growing in the surrounding habitat. Even on active railway tracks their number is relatively high (the seedlings of 18 woody species were found to occur along the active tracks, Table 2), which may be associated with the presence of trees and shrubs growing in the railway surroundings (wastelands, roadsides, squares, parks).

Development of the dendroflora could also be impeded in the case of unused railway tracks since these places can still be subjected to strong human pressure. The area of former railway land could be heavily trodden (footpaths were visible at our study sites: C1, D5, E3, G3 and H1, see Fig. 1 and Table 1). In addition maintenance practices are still carried out on some sections of unused tracks. For example, mowing is conducted regularly at site $\mathrm{C} 1$. We also observed that young trees had been cut down at site D1 (Table 1).

In most of the railway areas that were abandoned over 10 years ago the anthropogenic influences have become weaker and the diversity and size of the trees has increased. In the case of these areas the dendroflora is richer in species (the number of trees amounted to 42, Table 2) and changes in the vertical structure of vegetation have been observed. If a characteristic combination of species (especially plants of the herbaceous layer) is formed, a forest can develop. This is a long-term process which depends on the type of forest surrounding the railway area and the distance between the forest and the tracks. Among the sites investigated in the study, an exception is the section of the track A1 - "Białowieża Towarowa" (see Fig. 1 and Table 1). The tracks had been used extensively before the line was closed 20 years ago. A deciduous forest was located a few meters from the tracks. Today, small differences in vegetation between the railway area and its surroundings are recorded.

\subsection{Changes in the rate of regeneration of the flora}

The processes described above proceed parallely and at different rates. It is, therefore, difficult to determine the duration of the particular stages of development of the plant cover in abandoned railway areas (some authors, e.g. Brandes 1983, 2005; Kowarik \& Langer 1994 have attempted to distinguish particular stages of plant succession). The rapid retreat of therophytes and alien species (Brandes 1993a, 2004a, 2005; Gilbert 1989) is accompanied by an increase in the number of native species in the flora of abandoned railway areas. It takes a long time for a non-synanthropic species to return to these places. During this period the level of abiotic stress should decrease. According to Brandes (2004a) these changes can occur quite rapidly, even three years after the closure of the railway line. It is difficult to assume, however, whether the habitat conditions will be suitable for the growth of ephemeral apophytes and non-synanthropic plants.

Available literature describing the process of flora development in abandoned railway areas dealt mainly with railway stations (see e.g. Kowarik \& Tietz 1986; Kowarik \& Langer 1994; Brandes 2002a, 2004a; Schinninger et al. 2002, 2003; Piskorz \& Czarna 2006). These linear structures are located in rural or urban areas in ruderal surroundings rich with a great variety of species and having a small number of native species sensitive to human pressure. An abundant synanthropic vegetation develops along railway tracks running through railway stations (the effect of the specific composition of diaspore rain). The rate and directions of further changes in the plant cover cannot be fully predicted. The return of native species to abandoned railway areas is determined by a number of biotic and abiotic factors. Changes in the factors affecting the flora of railway areas are also difficult to foresee.

A better understanding of the processes taking place in abandoned railway areas would require several decades of observations in various parts of Central Europe. The data available in literature pertain to railway areas abandoned more than 50 (Kowarik \& Langer 2005), 15 (Schinninger et al. 2002, 2003; Piskorz \& Czarna 2006; Nowińska \& Czarna 2008) or several years ago (e.g. Brandes 2002a 4 years, Brandes $2004 \mathrm{a}-3$ years). In studies that involved the railway station in Berlin, the authors (Kowarik \& Tietz, 1986; Kowarik \& Langer 1994, 2005) describe a 40-year lasting process of vegetation succession. In other publications, field observations were performed only once (as in the case of our investigations). Based on the hitherto published results, we cannot determine the temporal regeneration dynamics of the native flora after the railway areas have been abandoned.

Our observations (conducted within a homogenous habitat) could provide a starting point for studies on the plant cover in abandoned railway areas (GPS coordinates of our study sites - see Table 1).

\section{Conclusions}

Trends in the transformation of the flora in abandoned railway areas are as follow:

- the retreat of aliens with a short life cycle (their role declined in just a few years after the closure of the railway lines);

- the encroachment of native perennials and trees (this long lasting process is determined by a number of biotic and abiotic factors). 


\section{Acknowledgements}

We wish to acknowledge our indebtedness to the Ministry of Science and Higher Education for grant No N305 076 $32 / 2694$ which made this work possible.

\section{References}

Böhmer H. J., 2001, Das Schmalblättrige Greiskraut (Senecio inaequidens DC. 1837) in Deutschland - eine aktuelle Bestandaufnahme, Flor. Rundbr. 35(1-2): 47-54.

Brandes D., 1983, Flora und Vegetation der Bahnhöfe Mitteleuropas, Phytocoenologia 11: 31-115.

Brandes D., 1993a, Eisenbahnanlagen als Untersuchungsgegenstand der Geobotanik, Tüexenia 13: 415-444.

Brandes D., 1993b, Zur Ruderalflora von Verkehrsanlagen in Magdeburg, Flor. Rundbr. 27(1): 50-54.

Brandes D., 2002a, Vascular flora of the Lüchow railway station (Lower Saxony, Germany), Working Group for Vegetation Ecology, Institute of Plant Biology, Technical University, Braunschweig, Retrieved 8 September 2012 form: http://www.ruderal-vegetation.de/epub/ vascular.pdf.

Brandes D., 2002b, Zur Flora des Bahnhofs KöstchachMauthen (Kärnten, Österreich), Retrieved 8 September 2012 form from: http://www.ruderal-vegetation.de/ epub/koetschach.pdf.

Brandes D., 2004a, Flora des ehemaligen Bahnhofs Dömitz (Elbe), Retrieved 8 September 2012 from: http://www. ruderal-vegetation.de/epub/bf_doemitz.pdf.

Brandes D., 2004b, Exkursionsziel Eisenbahnbrache? Der unerwartete Artenreichtum von innerstädtischen Eisenbahnflächen, Retrieved 8 September 2012 from: http:// www.ruderal-vegetation.de/epub/eisenbahnbrache.pdf.

Brandes D., 2005, Kormophytendiversität innerstädtischer Eisenbahnanlagen, Tüexenia 25: 269-284.

Brandes D., 2008, Bibliographie der Eisenbahnvegetation, Technische Universität Carolo-Wilhelmina, Universitätbibliothek, Braunschweig, Retrieved 8 September 2012 from: http://www.digibib.tu-bs.de/?docid=00021885.

Brandes D. \& Oppermann F., 1995. Straßen, Kanäle und Bahnanlagen ale lineare Strukturen in der Landschaft sowie deren Bedeutung für die Vegetation, Ber. Reinhold-Tüxen-Ges. 7: 89-110.

Büscher D., Keil P. \& Loos G. H., 2008, Neue Ausbreitungstendenzen von primär als Eisenbahnwanderer aufgetretenen Pflanzenarten im Ruhrgebiet: Die Beispiele Eragrostis minor, Geranium purpureum und Saxifraga tridactylites, Braunschweiger Geobot. Arb. 9: 97-106.

Chen H., Li S. \& Zhang Y., 2003, Impact of road construction on vegetation alongside Quinghai-Xizang highway and railway, Chin. Geogr. Sci. 13(4): 340-346.
Czarna A., 2005, Vascular flora of the railway station in Jarocin (Western Poland), Roczn. Akad. Roln. w Poznaniu 373: 39-46.

Eggert H., 1891, Catalogue of the Phanerogamous and Vascular Cryptogamous Plants in the Vicinity of St. Louis, Missouri, St. Louis.

Fornal-Pieniek B. \& Wysocki C., 2010, Flora nasypu nieużytkowanej linii kolejowej w okolicach Sokołowa Podlaskiego [Flora of a non-used railway embrankment near sokołów Podlaski], Woda - Środowisko - Obszary Wiejskie 10(3.31): 85-94.

Galera H., Sudnik-Wójcikowska B., Wierzbicka M. \& Wiłkomirski B., 2011, Encroachment of forest species into operating and abandoned railway areas in north-eastern Poland, Plant Biosystems 145(1): 23-36. [DOI 10.1080/11263504.2010.522803].

Galera H., Sudnik-Wójcikowska B., Ziętek D., Wierzbicka M. \& Wiłkomirski B., 2009, Biogeochemical correlation between habitat conditions and plant encroachment into abandoned railway lines in north-east Poland, [in:] Environmental changes and sustainability of biogeochemical cycling, $19^{\text {th }}$. International symposium on environmental biochemistry, 14-18 September 2009, Hamburg: 36.

Gilbert O. L., 1989, The ecology of urban habitats, Chapman and Hall, London, New York, Tokyo, Melbourne, Madras.

Gontier M., Balfors B. \& Mörtberg U., 2006, Biodiversity in environmental assessment - current practice and tools for prediction, Environ Impact. Asses Rev. 26: 268-286.

Hansen M. J. \& Clevenger A. P., 2005, The influence of disturbance and habitat on the presence of non-native plant species along transport corridors, Biol. Conservation 125: 249-259.

Hohla M., Kleesadl G. \& Melzer H., 2000, Neues zur Flora der oberösterreichischen Bahnanlagen mit Einbeziehung einiger grenznaher Bahnhöfe Bayerns, Beitr. Natkd. Oberösterr. 9: 191-250.

Hohla M., Kleesadl G. \& Melzer H., 2002, Neues zur Flora der oberösterreichischen Bahnanlagen mit Einbeziehung einiger grenznaher Bahnhöfe Bayerns - Fortsetzung. Beitr. Natkd. Oberösterr. 11: 507-578.

Hulten E. \& Fries M., 1986, Atlas of North European vascular plants, Vol. 2, Költz Sci. Books, Königstein.

Jehlik V., 1986, The vegetation of railways in Northern Bohemia (eastern part), Vegetace ČSSR A 14, Academia, Praha.

Kopecky K., 1971, Der Begriff der Linienmigration der Pflanzen und seine Analyse am Beispiel des baches Studený und der Strasse in seinem Tal, Folia Geobot. Phytotaxon. 6(3): 303-320.

Kornaś J., 1982, Man's impact upon the flora: processes and effects, Memorabilia zool. 37: 11-30. 
Kornaś J., Leśniowska I. \& Skrzywanek A., 1959, Obserwacja nad florą linii kolejowych i dworców towarowych w Krakowie [Observations on the flora of railway areas and freight stations in Cracow], Fragm. Flor. Geobot. 5(2): 199-216.

Kowarik I. \& Langer A., 1994, Vegetation einer Berliner Eisenbahnfläche (Schöneberger Südgelände) im vierten Jahrzehnt der Sukzession, Verh. Bot. Ver. Berl. Brandenb. 127: 5-43.

Kowarik I. \& Langer A., 2005, Natur-Park Südgelände: Linking Conservation and Recreation in an Abandoned Railyard in Berlin, [in:] I. Kowarik, S. Körner (eds.) Wild Urban Woodlands, Springer, Berlin, Heidelberg, New Perspectives for Urban Forestry: 287-299.

Kowarik I. \& Tietz B., 1986, Soils on ruined railway stations - The Anhalter Güterbahnhof, [in:] F. Alaily, R. Grenzius, M. Renger, K. Stahr, B. Tietz, G. Wessolek (eds.), Soilscapes of Berlin (West), Mitt. Dtsch. Bodenkdl. Ges. 50: 128-139.

Kryszak A., Kryszak J., Czemko M. \& Kalbarczyk M., 2006, Roślinność nasypów wybranych szlaków kolejowych [Vegetation of embrankment along selected railway lines], Zesz. Nauk. Uniw. Przyr. we Wrocławiu, Rolnictwo 88(545): 159-164.

Latowski K., 1972, Rzadziej spotykane rośliny naczyniowe linii kolejowej Poznań - Krzyż - Kostrzyn nad Odrą [Some rare vascular plants noted on railway-track Poznań-Krzyż-Kostrzyn on the Oder], Bad. Fizjogr. Pol. Zach. 25: 195-201.

Latowski K. \& Musiatowicz B., 2005, Flora roślin naczyniowych Wejherowa (Pomorze Gdańskie). Cz. I. Specyfika i prawidłowości flory terenów kolejowych [Flora of vascular plants of Wejherowo (Gdańskie Pomerania). Part 1. Character and regularity of the railway track flora], Acta Bot. Cassub. 5: 39-56.

Latowski K. \& Pardoł K., 2004, Właściwości flory synantropijnej terenów kolejowych Wielkopolskiego Parku Narodowego [Characteristics of the synanthropic flora of railway areas in Wielkopolski National Park], [in:] A. Kostrzewski, L. Kaczmarek, B. Walna (eds.), Stan i przemiany środowiska przyrodniczego Wielkopolskiego Parku Narodowego [The state and changes in the natural environment of the Wielkopolski National Park], Stacja Ekologiczna UAM, Poznań - Jeziory, Retrieved 8 September 2012 from: http://www.staff.amu. edu.pl/ jeziory/seminarium/21.PDF.

Lehmann E., 1895, Flora von Polnisch-Livland, Arch. Naturk. Liv-Ehst-Kurlands Ser. 2 Biol. Naturk. 11: $1-442$.

Nobis M. \& Nobis A., 2006, Interesujące, rzadkie i rozprzestrzeniające się gatunki roślin naczyniowych notowane na terenach kolejowych w południowo-wschodniej Polsce [Some interesting, rare and spreading species of vascular plants noted no railway tracks in the south-eastern Poland], Fragm. Florist. Geobot. Pol. 13(2): 301-308.

Nowińska R. \& Czarna A., 2008, Impact of Railway Facility Operation on Floral Growth in a Powodowo, the Region of Wielkopolska, Polish J. of Environ. Stud. 17.4: 613-621.

Partsch M. \& Karstner A., 1995, Flora und Vegetetion an Straßenrändern und Bahndämmen im Kreis Kötchen (Sachsen-Antalt), Hercynia (Halle) 29: 193-214.

Piskorz R. \& Czarna A., 2006, Vascular on a active and closed railway stations in Wolsztyn and its surroundings, Roczn. Akad. Roln. w Poznaniu 378, Bot.-Stec. 10: $137-156$

Radkowitsch A., 2003, Neophytic plants in Bavaria (Senecio inaequidens and Dittrichia graveolens), [in:] A. Zając, M. Zając, B. Zemanek (eds.), Phytogeographical problems of synanthropic plants, Institute of Botany Jagiellonian University, Cracow: 47-61.

Raunkiaer C., 1934, The life-forms of plants and statistical plant geography, Univ. Press, Oxford.

Schinninger I., Maier R. \& Punz W., 2002, Der stillegende Frachtbahnhof Wien-Nord. Standortbedingungen und ökologische Charakteristik der Gefäßpflanzen einer Bahnbrache, Verh. Zool-Bot. Ges. Wien 139: 1-10.

Schinninger I., Maier R. \& Punz W., 2003, Der stillegende Frachtbahnhof Wien-Nord. Stadtökologische und ökophysiologische Aspekte, IÖR-Schr. 39: 85-95.

Sendek A., 1973, Flora synantropijna terenów kolejowych węzła kluczborsko-oleskiego [The synanthropic flora of the Kluczbork-Olesko railway junction], Rocz. Muz. Górnośl. Bytom, Przyr. 6: 3-174.

Suominen J., 1969, The plant cover of Finnish railway embankments and the ecology of their species, Ann. Bot. Fenn. 6(3): 183-235.

Święs F. \& Wrzesień M., 2002, Rare vascular plants of the railway areas in Central-Eastern Poland. I. Lublin Upland, eastern part, Roztocze, Volhynia Upland, Ann. UMCS, sect. C 57: 95-117.

Tikka P. M., Koski P. S., Kivelä L. A. \& Kuitunen M. T., 2000, Can grassland plant communities be preserved on road and railway verges?, Appl. Veg. Sci. 3: 25-32.

Wiłkomirski B., Galera H., Sudnik-Wójcikowska B., Staszewski T. \& Malawska M., 2012, Railway Tracks - Habitat Conditions, Contamination, Floristic Settlement - A Review, Environment and Natural Resources Research 2(1); 86-95.

Wittig R., 2002, Ferns in a new role as a frequent constituent of railway flora in Central Europe, Flora 197: 341-350.

Wrzesień M. \& Święs F., 2006, Flora i zbiorowiska roślin naczyniowych terenów kolejowych zachodniej części Wyżyny Lubelskiej [Flora and Vascular plants Communities of Railway Areas of the Western Part of the Lublin Upland], M. Curie-Skłodowska Univ. Press, Lublin. 
